\title{
Implications of floodplain aquaculture enclosure ${ }^{1}$
}

\author{
Parvin Sultana and Paul Thompson ${ }^{2}$
}

\begin{abstract}
Bangladesh has extensive floodplain wetlands covering over 4 million ha. These remain an important source of livelihood - fish contribute about $60 \%$ of national animal protein consumption, and wetland plants are used for fodder, food and construction. Over fishing, short term leasing of use rights, flood control and drainage, and pollution all have negative impacts. In contrast several projects have helped establish local community management in many of these commons, and in these areas fisheries and wetland productivity have been restored through simple measures such as sanctuaries and closed seasons.
\end{abstract}

However, community organisations and poor floodplain users face a new threat in the private lands that are seasonally flooded and form a major part of Bangladesh's freshwater wetlands:

- In the last decade the area of private seasonally flooded land enclosed with bunds and fences for monsoon aquaculture grew by $30-100 \%$ a year depending on the location. This trend shows no sign of slowing.

- In different regions this is organised by individual landowners, informal groups, or companies that lease in land.

- These systems are productive but have high input costs, and catches of wild fish decline.

- Large farmers are the main beneficiaries, by operating aquaculture, as investor share-holders, or by receiving payment for use of their land.

- In all cases poorer people report that they loose. The landless loose access to natural fisheries and other aquatic resources, although some gain employment. Marginal farmers and sharecroppers loose both common aquatic resources and access to land for cultivation.

The Government of Bangladesh, some donor projects and NGOs are promoting enclosure, but instead of being subsidised this private enterprise should be regulated before loss of natural floodplain fisheries and inequality become too widespread.

\section{KEY WORDS}

Bangladesh, fisheries, commons, enclosure, floodplain

\footnotetext{
${ }^{1}$ Paper submitted to International Association for the Study of Commons 2011 conference, Hyderabad, India, January 2011 as part of a Panel on Adaptive learning for improved management of commons

${ }^{2}$ Flood Hazard Research Centre, Middlesex University, Trent Park, Bramley Road, London N14 4 YZ. <parvin@agni.com>
} 


\section{CONTEXT}

Floodplains have always been under great pressure since they became the starting place of civilisation. Floodplains are amongst the richest ecological systems on the planet (Ramsar 2001) with the potential for highly productive arable farming when not flooded. Hence, human interventions to change their hydrological regime also began early (Hillel 1992). Now floodplains are amongst the most densely populated and productive areas of the planet. For example, Bangladesh with about two-thirds of the country comprising floodplains in the Ganges-Brahmaputra delta (Brammer 2000 ) has the largest concentrated population of poor flood prone people in the world with about 1,000 people/ $\mathrm{km}^{2}$ and a gross domestic product of $\$$ US $539,000 / \mathrm{km}^{2}$ in 2008 , higher than a dozen of the States that make up the USA. Human settlement is at the cost of declining natural wetlands, and these populations will be at an increasing risk from flooding with climate change. However, whereas a process of draining floodplains for arable uses was largely completed by the end of the nineteenth century in western Europe (Wagret 1967), much of Asia's deltas remain wetlands, partly because they are used to grow rice.

These complex systems combine a range of property rights. Public lands are usually areas with permanent water. But seasonal floodplains have for many years been de jure or de facto private land: individuals have the right to sell the land and to decide what crops to grow there. Nevertheless these areas are a vital part of capture fisheries where fish breed and grow out during inundation, before moving to deeper areas for the dry season. Wetlands provide common pool resources such as fish, plants, grazing and other services which have been important but undervalued for the nutrition and income of poor people for generations. A new trend of private enclosure of floodplains for aquaculture is taking place in Asia, ostensibly this retains their wetland status but the extent and impacts on poor people, on aquatic resources, and on the wider floodplain system and vulnerabilities are unclear.

Enclosure is not a new concept or issue. For example, in Britain, conversion of common land to private crop fields in the $15^{\text {th }}$ to $18^{\text {th }}$ centuries involved a change from a system of common property to private property rights ('enclosure'). In turn, that conversion shifted rural populations to a money based economy since it was no longer possible for commoners to be self-sufficient. Whether this process was accompanied by a gain in agricultural productivity is contested (Chambers and Mingay 1966; Crafts 1985; Overton 1996), as is its impact on migration (Allen 1992; Neeson 1993), but there is general acceptance that there was a redistributive impact away from the rural poor (Hammond and Hammond [1911] 1987; Neeson 1993).

\section{Enclosure in Bangladesh floodplains}

The current situation in Asian floodplains differs: there is a new recognition of the importance of the environment both in general and as a source of resources. There is increasing evidence of the significance of seasonal and year-round common pool resources in floodplains as a source of livelihood for the poor especially in times of stress. Some research has shown that fuel and construction wood, fodder, and wild crops from commons are important to relatively high income families as well as the poor (Narain et al. 2005). Some economic analyses have concluded that the conversion of wetlands to intensive agriculture reduces the productivity of the area. 
For example, in one wetland in Bangladesh the return from existing wetland products and services was US\$650 per ha in 2001, double that of rice (Thompson and Colavito 2007).

The extensive floodplain wetlands of Bangladesh remain an important source of livelihood - fish contribute about $60 \%$ of national animal protein consumption, and wetland plants are used for fodder, food and construction. Over fishing, short term leasing of use rights, flood control and drainage, and pollution all have negative impacts. Since the early 1990s community based co-management has been extended as an effective way of maintaining and restoring productivity of existing floodplain resources. In Bangladesh this has involved government and nongovernment organisation (NGO) projects for water resource management (Soussan and Datta 1998; Ministry for Water Resources 2001) and for fisheries management (Middendorp et al. 1999; Thompson et al. 2003) that have resulted in several hundred community organisations with rights over areas of floodplain taking up simple measures such as fish sanctuaries and closed seasons.

In Bangladesh most privately owned land in floodplains becomes during the monsoon a seasonal common pool resource where local people, including the poor, can catch fish or collect aquatic plants, snails and other produce. When water levels fall the area reverts to exclusive access for the landowners. However, community organisations and poor floodplain users face a new threat in the private lands that are seasonally flooded and form a major part of Bangladesh's freshwater wetlands.

There are three separate but similar movements to enclose floodplain land for aquaculture in Bangladesh, based on differences in the main species cultivated:

- In coastal areas lands have been enclosed with bunds since the 1980s to cultivate Black Tiger Shrimp Penaeus monodon. This has received extensive study (for example, Rahman et al. 2006) and is not considered further here.

- Particularly in southern floodplains farmers have bunded fields to grow giant freshwater prawns Macrobrachium rosenbergii.

- In several areas groups of people have cooperated to make bunds and/or use nets to enclose larger areas of private land to cultivate freshwater fin-fish (mainly carps) during the monsoon. This latter approach started on a larger scale with substantial private embankments in Daudkandi Upazila of Comilla District initiated with support of an NGO Shisuk in the late 1990s, but smaller enclosures with a similar purpose have been developed for group "rice-fish" culture in several regions.

By providing a production oriented narrative the "Daudkandi model" has recently received considerable policy attention in Bangladesh, particularly when coupled with the local company approach and promise of reserving some shares for the poor promoted by Shisuk. However, there have been few independent assessments of this approach. Mustafa and Brooks (2009) considered the technical performance of four floodplain enclosures in Daudkandi and found production of 1.5-1.8 t/ha/year, but with high costs, so that the net income was about Tk 13 per kg produced or Tk 26,000 per ha. Toufique and Gregory (2008) investigated the Daudkandi model in two villages and found qualitative evidence that the benefits of floodplain aquaculture tend to accrue to better off people, with elite capture of the boards of the companies formed for this enterprise, few shares in the hands of poorer farmers, and loss of 
access to seasonal wild fish for the landless.

Bangladesh's current fisheries policy regarding floodplain aquaculture is unclear. The National Fisheries Strategy and Action Plan (Department of Fisheries 2006) recommends a precautionary approach. The Fisheries Sub-Sector Road Map for 2006-2015, proposes to zone aquatic resource use including areas for open water fisheries, and areas suitable for floodplain aquaculture. The road map highlighted floodplain aquaculture as an approach to promote in areas where it was socially and environmentally appropriate.

\section{METHODS}

This study investigated the extent and trend of enclosure; management arrangements; and implications on local stakeholders, particularly the poor. Three study areas know to have had recent development of aquaculture enclosures were selected representing the physical characteristics and institutional arrangements current in Bangladesh:

- Comilla in the eastern region (large company managed enclosures, with and without NGO support);

- Gazipur in the north-central region (medium sized group managed enclosures); and

- Narail in the south-west region (small individually managed enclosures).

In each area two union parishads (a local council, the smallest administrative area) in one sub-district were purposively selected, where there was a concentration of enclosures based on advice from local Department of Fisheries officials. Here research assistants compiled an inventory of enclosures. Overall 568 aquaculture enclosures were inventoried and mapped to determine the areas enclosed and their characteristics, the dates of enclosure, and changes in de facto water, fishery and land tenure (Table 1).

Table 1 Study areas and number of enclosures for floodplain aquaculture

\begin{tabular}{|l|l|l|c|c|}
\hline District & Upazila & Union & $\begin{array}{c}\text { Enclosures } \\
\text { in inventory }\end{array}$ & $\begin{array}{c}\text { Enclosures } \\
\text { investigated in detail }\end{array}$ \\
\hline Comilla & Daudkandi & South and North Elliotganj & 37 & 15 \\
\hline Gazipur & Kapasia & Durgapur, Toke & 107 & 5 \\
\hline Narail & Sadar & Shekhati, Singhasail & 424 & 10 \\
\hline Total & & & 568 & 30 \\
\hline
\end{tabular}

For more in-depth study case studies were used to understand the processes, history and practice of representative enclosures covering all types and institutional arrangements found in the inventory. Key informant interviews and two focus group discussions were held separately with enclosure participants and with other landless floodplain natural resource users in each of 30 enclosure/floodplain sites (10 in Narail, 15 in Comilla and 5 in Gazipur). More sites were investigated in Comilla to capture the wider range of institutional and management arrangements and because of national debate over the spread of the "Daudkandi" model of floodplain aquaculture from Comilla. 


\section{RESULTS}

\section{Enclosure trend}

In the last decade the area of private seasonally flooded land enclosed for monsoon aquaculture was found to have grown by $30-100 \%$ a year. This trend shows no sign of slowing, although the recent history of aquaculture enclosures differs in some regards in each study area.

In Kapasia in Gazipur the small seasonal beels (floodplain depressions) are part surrounded by slightly higher land. In the early 1990s a WorldFish Center project on aquaculture technology promoted cultivation of fish in some of these beels. This practice continued, and in the late 1990s about a third of such beels were found to be stocked by groups of farmers (Thompson et al. 2005). The present study shows the trend continued at a similar pace in the last two decades (Fig. 1).

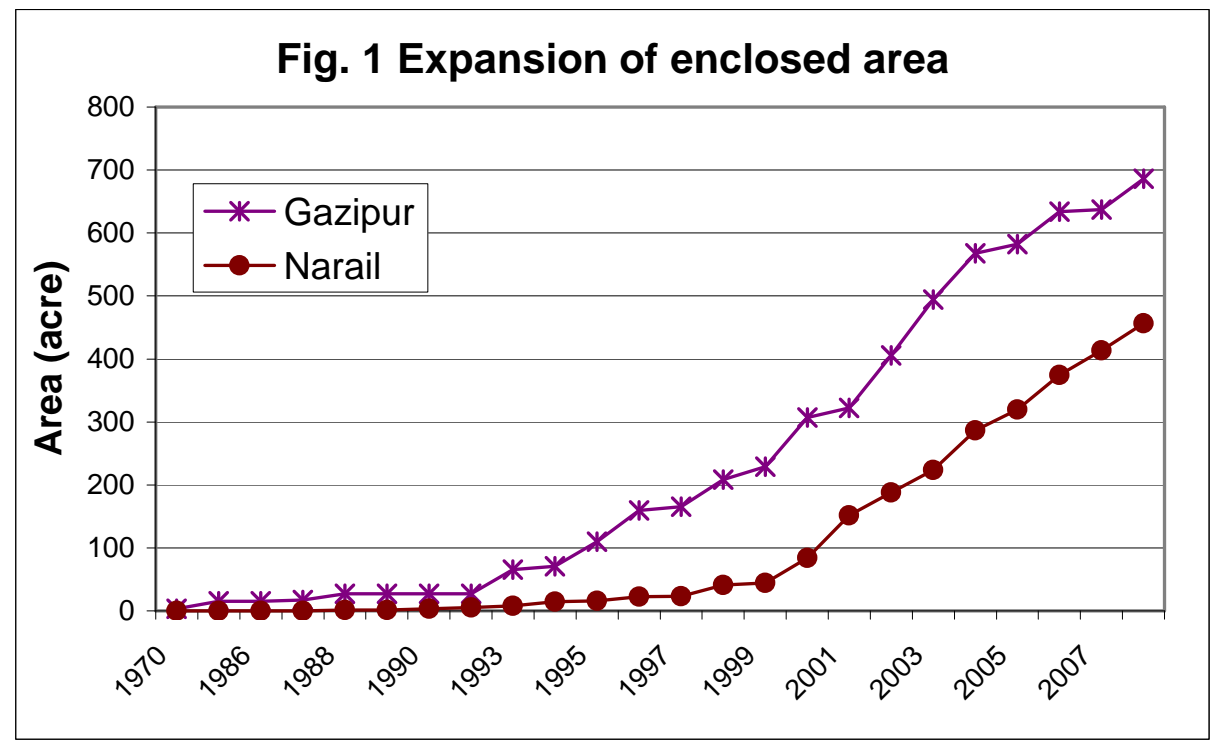

In Narail Sadar there are extensive seasonal floodplains and beels. Cultivation of freshwater prawns started here in the early 1990s in ponds through extension by government and NGOs. But in the last decade individual farmers have started to make small bunds or use fences around individual plots and khals to grow fish and prawns. This has proved profitable and is rapidly expanding (Fig. 1).

Fig. 2 shows an example of the extent of enclosure of private floodplain land for aquaculture in Atrai Beel a seasonal floodplain where individual initiatives by farmers have changed access and use in a substantial part of the area. This is despite the area having an ongoing community initiative for openwater fishery management. Some older ponds used for aquaculture, and recent enclosures in the south-east corner of the image which lie within another beel are not shaded. 


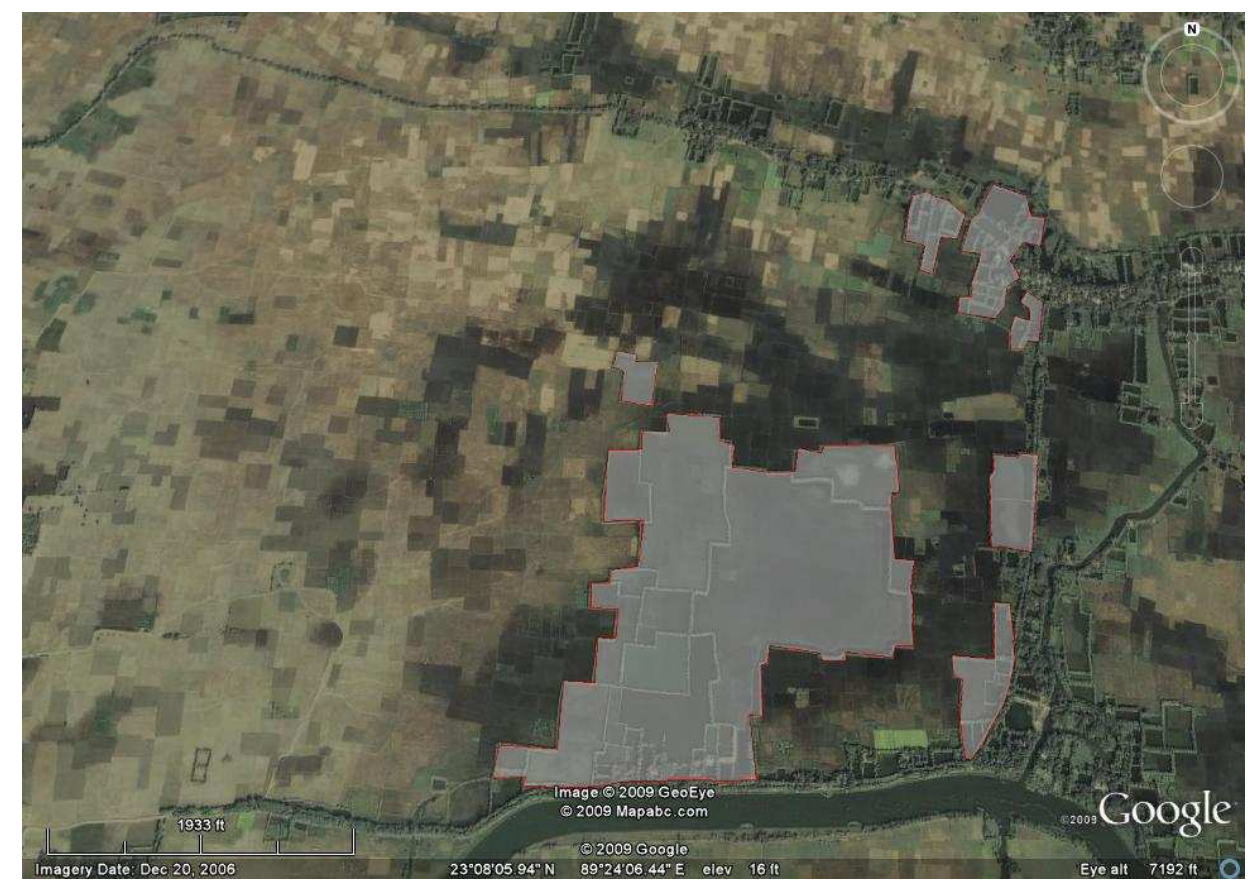

Fig 2. Areas of small enclosures for aquaculture made in Atrai Beel, Narail (grey shaded areas)

In Daudkandi in Comilla completion in 1992 of an embankment protecting the area from flash floods transformed opportunities. Some private attempts at floodplain aquaculture were made, but the first successful initiative was the Pankowri Fisheries Project started by Shisuk in 1996. News of the production from this approach spread and was copied by private initiatives to form companies and sell shares to raise capital to make embankments and then intensively cultivate fish, particularly in the early 2000s when substantial areas rapidly went into floodplain aquaculture (Fig. 3).

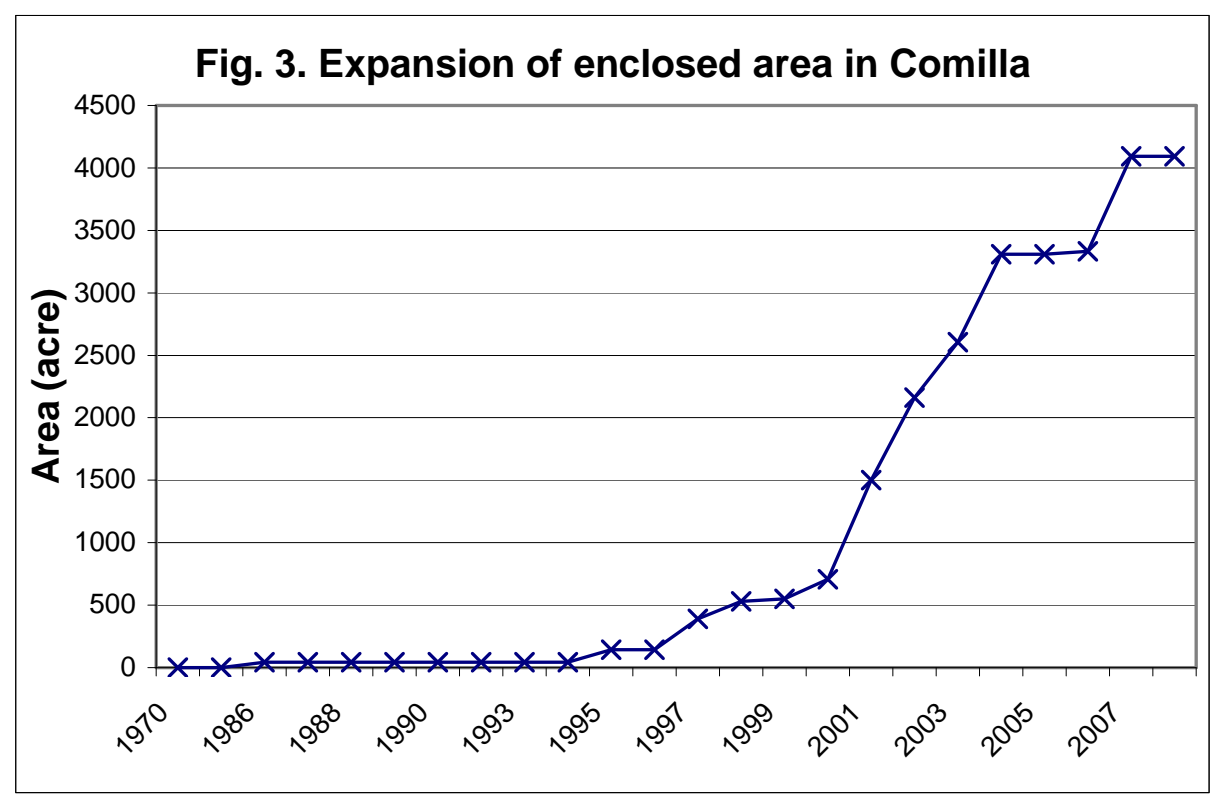

Standardising the area of floodplain aquaculture enclosures as a percentage of the 2008 area (Fig. 4) reveals the differences in timing and rates of growth - with earlier and more gradual expansion in Gazipur, and a very rapid expansion in Comilla. 


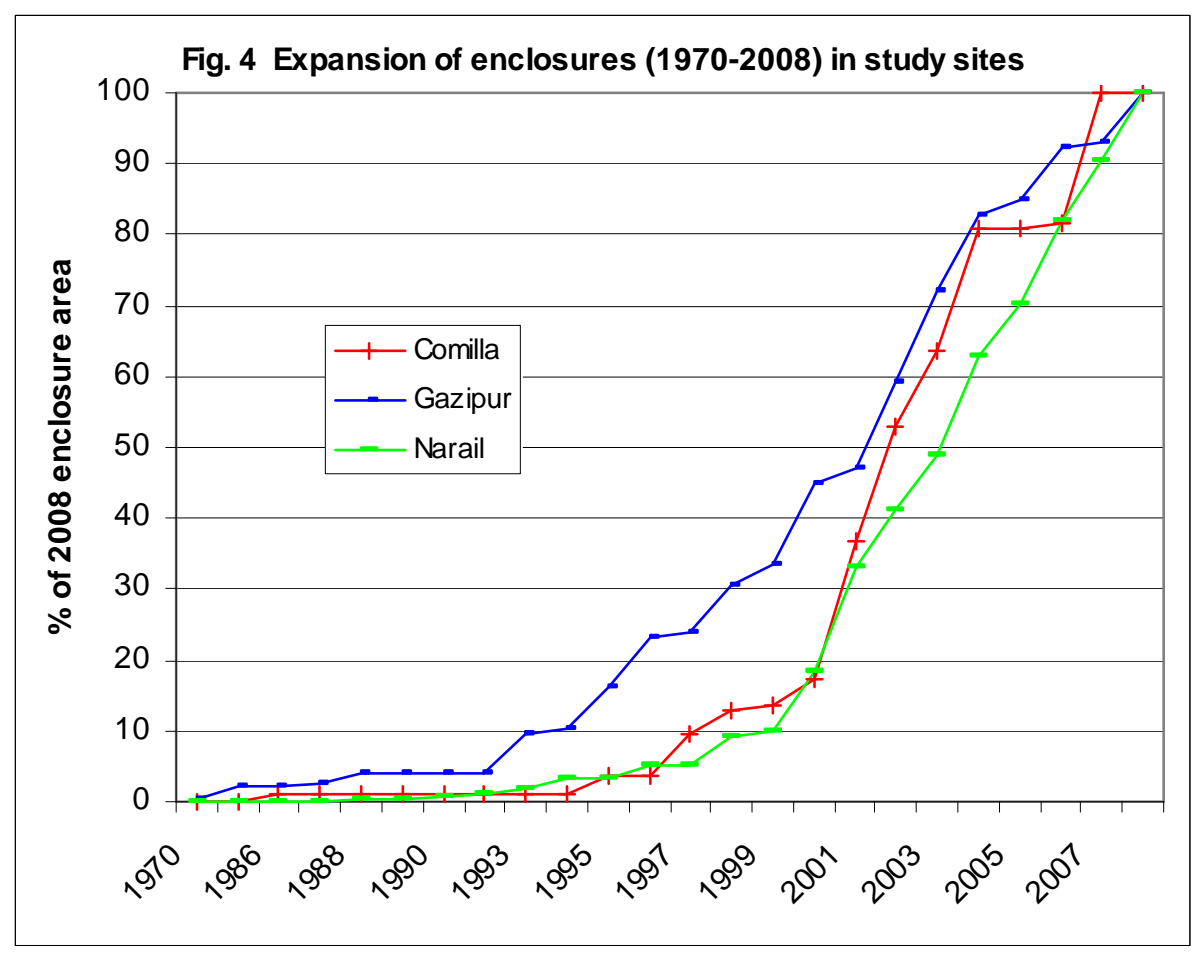

By 2008 over three quarters of the suitable floodplain area in the Daudkandi study area was enclosed, with the average enclosure covering 36 ha, and over half of suitable areas in Kapasia were enclosed (average area just under 2 ha). Despite the growth of hundreds of small enclosures in Narail, because these are individual operations averaging 0.3 ha they only cover a small part of the floodplains (Table 2).

Table 2 Enclosure coverage in 2008 in the study areas

\begin{tabular}{|l|c|c|c|}
\hline District & $\begin{array}{c}\text { Average enclosure } \\
\text { area (acres) }\end{array}$ & $\begin{array}{c}\text { Total enclosure } \\
\text { area (acres) }\end{array}$ & $\begin{array}{c}\% \text { of floodplain } \\
\text { enclosed }\end{array}$ \\
\hline Comilla & 88.8 & 4,092 & 77 \\
\hline Gazipur & 4.8 & 686 & 58 \\
\hline Narail & 0.9 & 456 & 3 \\
\hline
\end{tabular}

\section{Enclosure management}

Institutional arrangements for enclosures differ greatly by region and scale of enclosure.

In Comilla all enclosures are run by joint stock companies with most initiated by local shareholders. The land is accessed either through fixed rate leases or as shareholders or a combination (Fig. 5). On average 205 persons share in the profits per enclosure. Embankments and the sluice gates built in $50 \%$ of enclosures were financed by selling shares. NGOs have a role in $15 \%$ of these enclosures, but none in the other study areas. These are the only enclosures where there are any poor non-landowning participants, but only $9 \%$ of shareholders were found to be poor. 


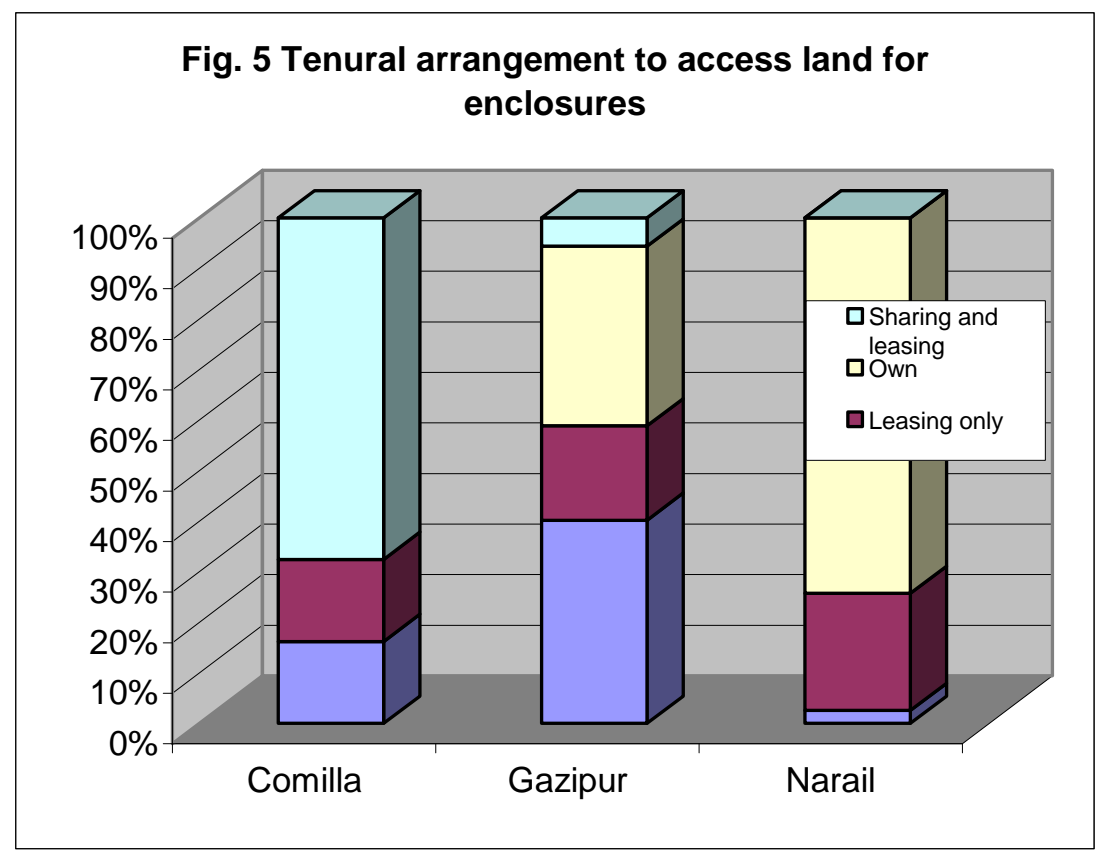

In Gazipur about half the enclosures are individual initiatives and half were established by informal groups, with about $60 \%$ of land accessed through leases and share arrangements. Finance is from the participants' own funds. The areas are naturally partially enclosed by higher land so netting is used in half of them. Despite having on average only eight participants per enclosure, these groups are prone to internal disputes and some fail after a few years.

In Narail all of the enclosures are individual farmer operations, most on their own land with only about $20 \%$ of the enclosed land leased. Although most of these operations are self-funded, $45 \%$ obtained loans secured on their land from banks, NGOs or moneylenders, unlike the operations in the other two areas (Table 3).

Table 3 Main source of funds for establishing enclosure (\% of enclosures)

\begin{tabular}{|l|r|r|r|r|r|}
\hline Location & Personal & Moneylender & Bank & NGO & Selling shares \\
\hline Narail & 55 & 10 & 20 & 15 & 0 \\
\hline Comilla & 17 & 0 & 0 & 13 & 70 \\
\hline Gazipur & 90 & 0 & 10 & 0 & 0 \\
\hline
\end{tabular}

Fishery impacts

The enclosures are stocked each year, mostly with a mix of native and exotic carp species (Fig. 6). In Comilla tilapia (an exotic) is also commonly used, while in the small Narail enclosures freshwater prawns (golda) are stocked in almost all enclosures along with a smaller number of carp species. Golda has a high value but requires more intensive management possible in small individual plots, and post larvae are also more readily available in this area. 


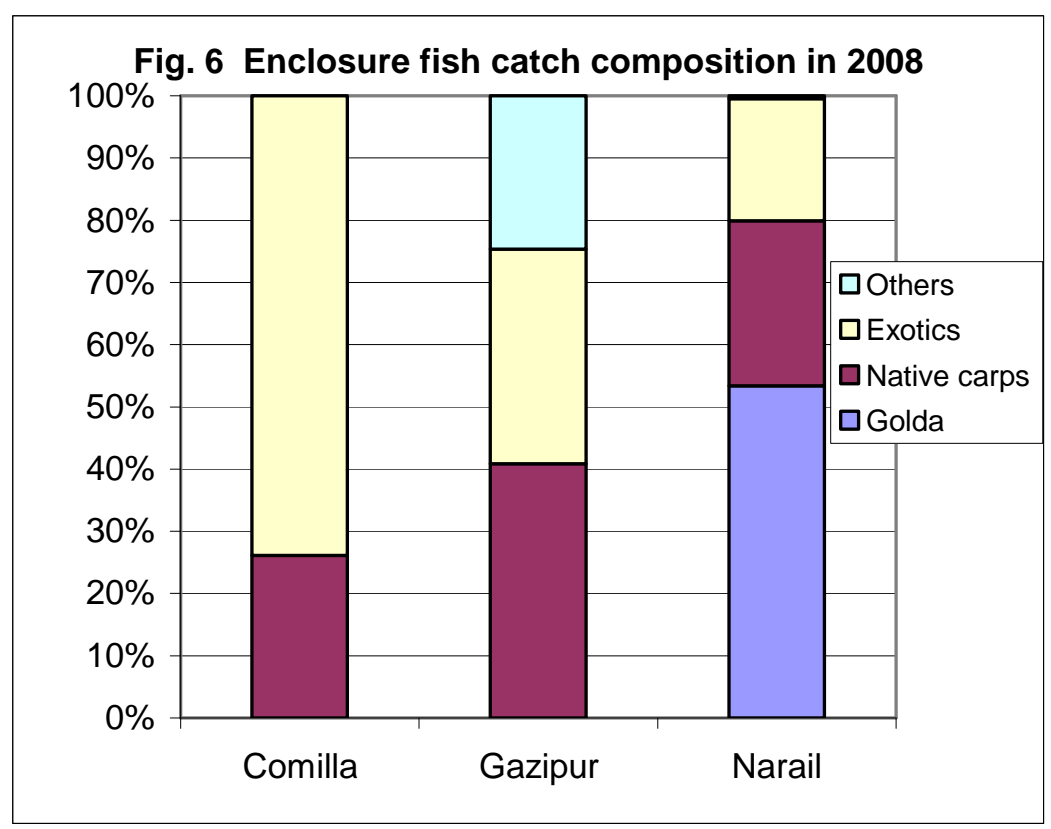

Consequently exotics dominate production in Comilla, and with intensive stocking production levels are much higher than in the other areas and are comparable to the yields of many aquaculture ponds (Table 4), but costs are high. In Gazipur yields are much lower and have reportedly declined since enclosures were established, with wild fish a significant but declining component of catches. In Narail yields are also modest in physical terms, but since freshwater prawns (golda) have a high value the return is substantial.

Table 4 Catch of stocked fish reported from enclosures.

\begin{tabular}{|l|r|r|}
\hline \multirow{2}{*}{ Site } & \multicolumn{2}{|c|}{ Fish catch (kg/ha) } \\
\cline { 2 - 3 } & Start & \multicolumn{1}{|c|}{ Now } \\
\hline Comilla (12 enclosures) & 1,760 & 2,230 \\
\hline Gazipur (4 enclosures) & 610 & 280 \\
\hline Narail (10 enclosures) & 680 & 640 \\
\hline
\end{tabular}

In all three study areas the catch of wild fish from the floodplains that have been enclosed is reported to have fallen substantially to:

- $50 \%$ of the pre-enclosed level in Comilla,

- $58 \%$ of the earlier level in Narail, and

- $44 \%$ of the earlier level in Gazipur.

This has a knock on consequence for loss of nutrition and income for the poor who earlier could catch wild fish in the open floodplain, but now are prevented from fishing by those managing the enclosures. Moreover, the diversity of wild fish has declined considerably, as shown in Fig. 7 for the Comilla study area. These smaller native fishes lost from floodplains are of higher nutritional value and were more accessible for the poor than the carps grown in floodplain enclosures (Thompson et al. 2002). 


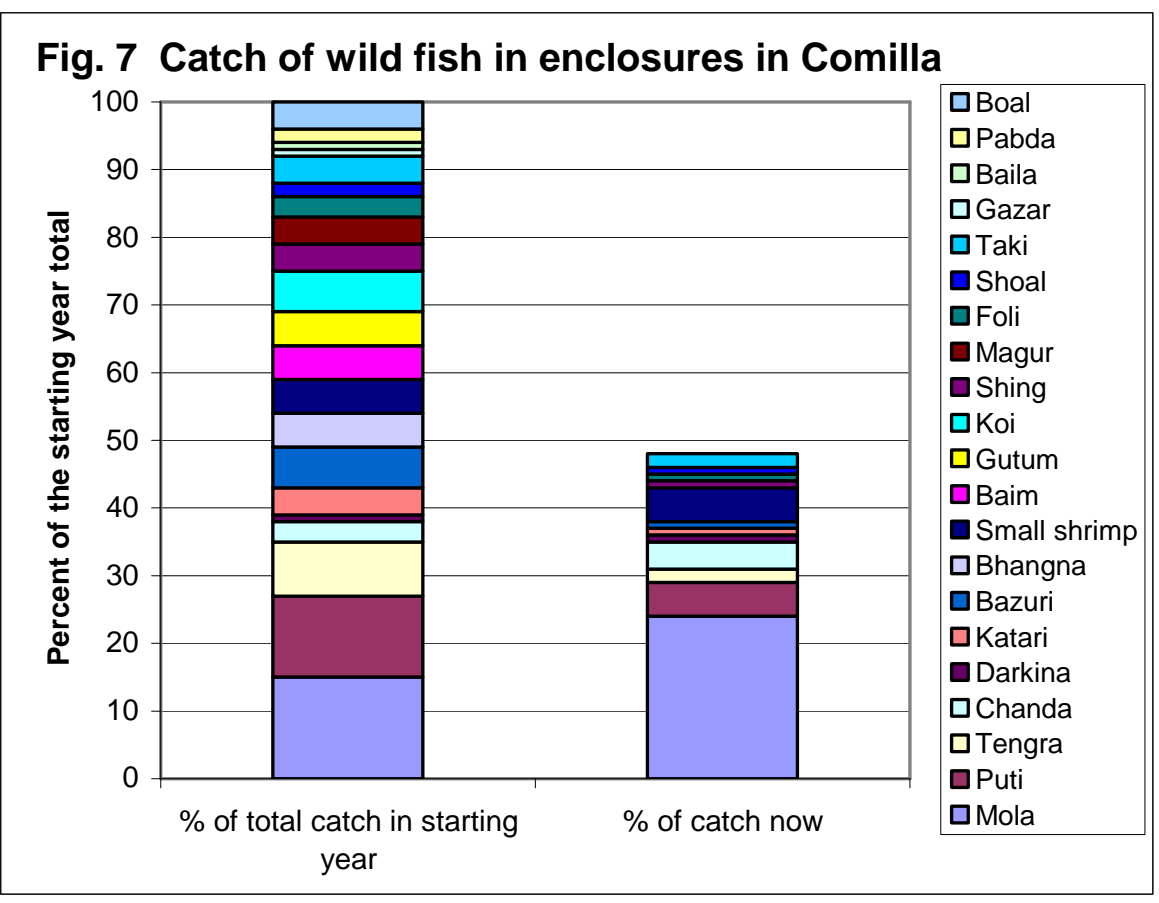

Agriculture and environmental impacts

Impacts of enclosures on agriculture have been limited. There was little monsoon cultivation before due to flooding, except in Narail where enclosure owners have replaced aus (early monsoon season) rice, aman (late monsoon season) rice varieties and jute with fish. Since enclosures started, in the dry season cultivation of high yielding varieties of rice has expanded at the expense of local rice varieties and other crops. But apart from irrigated rice, other dry season crops have been lost and in some areas enclosures were blamed for causing increased waterlogging.

One positive impact of floodplain aquaculture is that before enclosure high pesticide use was reported in all the study areas during the dry season, but now all of the sites investigated report reduced use of pesticide or switching to integrated pest management so that fish are not harmed by agro-chemicals.

The physical structures and complexity of the enclosures also differs by region and scale of operation. Almost all enclosures in Narail and Comilla use earthen embankments, but in Gazipur bamboo fences or metal grills are commonly used to block outlets from areas naturally enclosed by slightly higher land and allow some passage of water. Also over half of the larger more complex enclosures of Comilla include a water control structure (Fig. 8). 


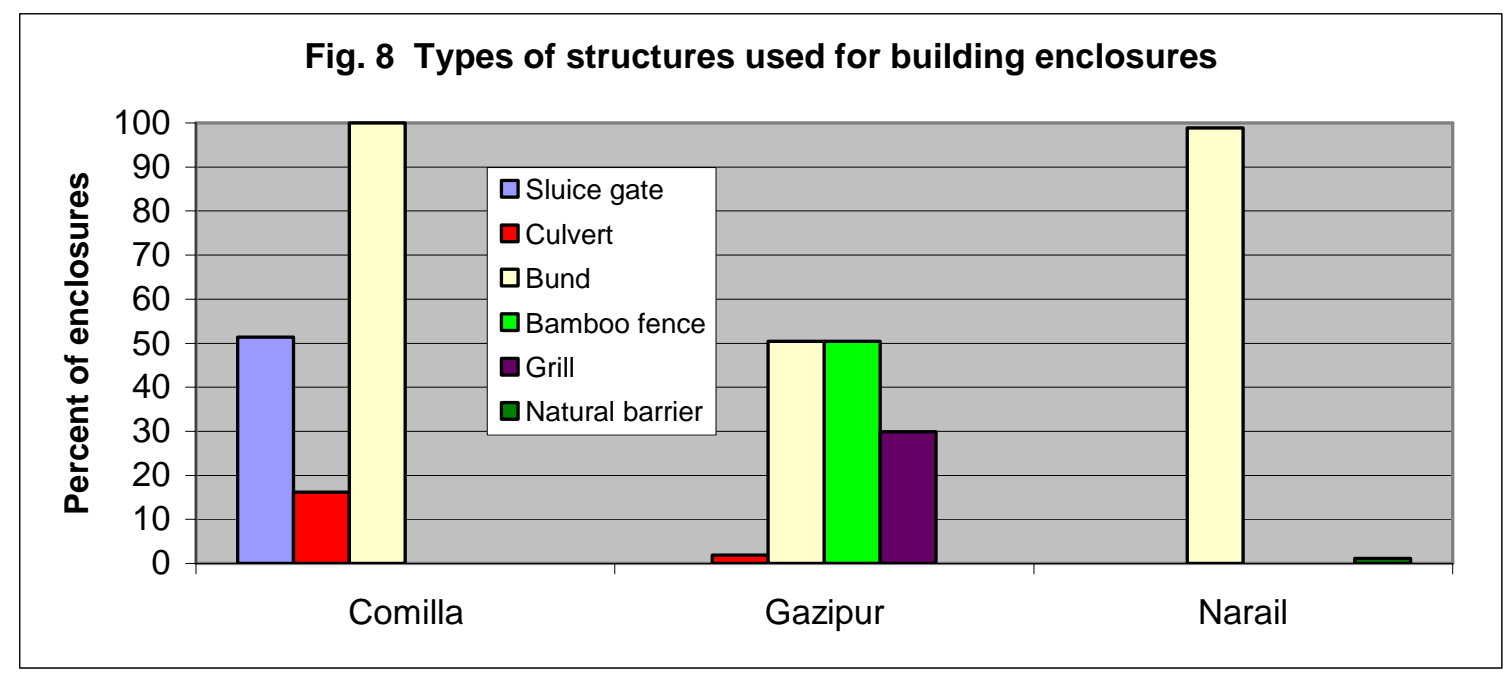

Associated with the physical interventions, siltation was reported to have increased in Daudkandi and Narail due to wash-off of earth from bunds and embankments. Consequently in these areas local people report that there is increased waterlogging in beels and floodplains due to siltation of canals, that fish migration routes have been hampered due to siltation, and that fertile silt is not brought in as water flows are reduced.

\section{Distributional implications}

Through stakeholder discussions it was estimated that about half of the local communities in Comilla and Narail have some involvement in enclosures (owning or being directly involved in the operation, investing/owning shares in it, leasing land to the operators, working for them, or supplying inputs). However, linkages and wider involvement are less in Gazipur where only $16 \%$ of people have such involvement. In all three areas it was found that access to natural aquatic flora and fauna, particularly wild fish, had been lost or much reduced for all stakeholders particularly the poor and fishers. The impact of enclosures has been to widen inequality in the floodplains studied: the better off gain, while most of the poor said they lost.

Considering changes in fish and crop production, in Narail landowners who enclose their own land achieve an increase in their net returns of about Tk 6,200 per acre (Tk 15,300 per ha, or about US\$225 per ha in 2008). However, there has been a cumulative loss of access and incomes from wild natural resources. Table 5 indicates a loss of access (and most likely quantities) not only of natural fish but also of aquatic plants, snails and grazing. This has had a greater impact on the local poor - landless men and women, fishers and marginal farmers - who previously could collect these resources freely during the monsoon.

Table 5 Change in access to natural resources reported in 2008 compared with pre-enclosure conditions (average score in focus groups on a scale from maximum improvement +5 to maximum loss -5)

\begin{tabular}{|l|c|c|c|c|}
\hline Site & Natural fish & Aquatic plants & Snails & Grazing \\
\hline Comilla & -5.0 & -1.6 & -1.5 & -1.4 \\
\hline Gazipur & -4.8 & & & \\
\hline Narail & -3.0 & -3.0 & -2.7 & -3.0 \\
\hline
\end{tabular}


In Kapasia, Gazipur landowners have enjoyed a modest increase in income as fixed rents from groups leasing an enclosure, but most of the benefit goes to the enclosure group. All stakeholders have almost completely lost access to wild fish, but other commons resources were not reported to have been important. In Comilla all categories of stakeholder reported loosing access to wild fish when floodplains are enclosed, although loss of access to other aquatic resources is not so strong. However, in the Comilla enclosures the financial returns to shareholders were reported to be modest because of high costs for intensive stocking and for leasing land (about $83 \%$ of gross income from enclosures).

Overall there is consensus that larger farmers have gained from enclosures in all the areas, and that marginal farmers have lost in all the areas (lost access to natural resources and land to sharecrop). The overall livelihood impact on the landless has been smaller but negative. Although in Comilla those involved in enclosures think fishers have gained employment, non-participants in enclosures (the poor, including fishers) say they have lost (Table 6).

Table 6 Opinions on change in livelihood for different stakeholders with enclosures (based on separate focus groups of enclosure owners/ shareholders, and poor non-participants shown as columns; scale +5 to -5 )

\begin{tabular}{|l|c|c|c|c|c|c|}
\hline \multirow{2}{*}{ Stakeholders } & \multicolumn{2}{|c|}{ Narail } & \multicolumn{2}{c|}{ Comilla } & \multicolumn{2}{c|}{ Gazipur } \\
\cline { 2 - 7 } & $\begin{array}{c}\text { Enclosure } \\
\text { participant }\end{array}$ & $\begin{array}{c}\text { Poor non- } \\
\text { participant }\end{array}$ & $\begin{array}{c}\text { Enclosure } \\
\text { participant }\end{array}$ & $\begin{array}{c}\text { Poor non- } \\
\text { participant }\end{array}$ & $\begin{array}{c}\text { Enclosure } \\
\text { participant }\end{array}$ & $\begin{array}{c}\text { Poor non- } \\
\text { participant }\end{array}$ \\
\hline Fishers & -0.7 & -2.1 & 1.9 & -1.4 & -0.4 & -2.0 \\
\hline Landless & 0.8 & 0 & 0.9 & -1.2 & 0.6 & -0.4 \\
\hline Marginal farmers & -1.2 & -1.3 & -0.7 & -2.9 & -2.4 & -1.8 \\
\hline Small farmers & -1.3 & -1.3 & 0.6 & -1.7 & 0.6 & 0.6 \\
\hline Large farmers & 1.1 & 0.7 & 2.6 & 2.5 & 2.5 & 2.8 \\
\hline Poor women & 1.6 & 1.0 & 1.0 & & & 1.5 \\
\hline Fry traders & 1.8 & 1.6 & & & & \\
\hline
\end{tabular}

Blank indicates the focus group thought these stakeholders not significant in their area.

Hence the main beneficiaries have been larger farmers either from cultivating fish themselves when their land gave little agricultural output in the monsoon, or as shareholders in an enclosure, or by leasing use of their land in the monsoon to an individual or company operating an enclosure. While there are decreased opportunities for fishers, it is the marginal farmers and sharecroppers who have been worse affected as they no longer can access land for cultivation, and have lost access to aquatic resources and income. In addition, in larger enclosures the rights of landowners are not legally secured, and in some of these areas political influence has resulted in grabbing resources in the enclosure systems.

\section{CONCLUSIONS AND POLICY IMPLICATIONS}

\section{Conclusions}

The study reveals the following key findings in Bangladesh:

1. Rapid expansion of enclosures for aquaculture is taking place in widely separated floodplains.

2. Fish production has increased as there are high yields from stocking compared with the natural fisheries that are replaced. 
3. Dry season rice cultivation in enclosures is more environmentally friendly but other crops have been lost.

4. Siltation has worsened where bunds are made due to slippage.

5. The poor have lost access to common pool resources of natural aquatic flora and fauna, resulting in loss of nutrition and income.

6. Enclosures appear to widen inequality - the better off gain, most of the poor said they lost. In particular the main beneficiaries are larger farmers. Marginal farmers and sharecroppers are worse hit (losing access to land and subsistence fishing).

7. In larger enclosures the distribution of income through dividends on shares is much less than expected as operating costs are high - significant returns to shareholders are more of a conceptual ideal than a reality.

8. The institutional arrangements for larger enclosures are weak and varied. There has been political influence and land grabbing for enclosures in some areas, and in larger enclosures the rights of the landowners not legally secured.

\section{Policy implications and recommendations}

This study clearly indicates that, despite being productive, enclosing floodplains for aquaculture has a negative impact on the poor. Given that many individuals and groups of people are now investing in aquaculture enclosure, there is no justification for public funds or projects to subsidise this. However, the Government of Bangladesh, some donor projects and NGOs are now promoting enclosures for floodplain aquaculture as a way of boosting fish production and to promote private enterprise. Instead of being subsidised this form of private enterprise should be regulated before loss of floodplain fisheries commons and inequality become too widespread.

Overall there is neither a clear policy nor enforcement of any regulations that might limit the extent of enclosures or ensure good practices. Because floodplain aquaculture takes place on private land, there is limited scope to regulate these changes even when they affect seasonal common resources. Any official promotion of floodplain aquaculture in the interests of fish production, needs to be balanced with needs to maintain ecosystem functions and services, to achieve poverty reduction, and to recognize customary access to floodplain resources.

We recommend that floodplains should be zoned. Enclosures could then be allowed in certain areas where enclosing floodplain will not harm the environment. But floodplain connections that are vital for fish movement and drainage should be protected from being blocked by private (and public) embankments. Overall land use policies should regulate floodplain aquaculture development so that larger floodplainwetland systems with significant fisheries are maintained as open not-enclosed systems, while allowing enclosure of smaller floodplain areas that are not part of significant natural fisheries.

Enforcement of policy changes and regulations to limit enclosure will require a process for reviewing and deciding whether to permit larger enclosures, considering environmental functions, and customary access to floodplain resources. This cannot only be top-down. Awareness should be raised among floodplain communities of the 
risks from enclosure, and existing community organizations encouraged to make local plans that limit the spread of smaller enclosures since these can cumulatively have a major impact.

This recent experience in Bangladesh highlights issues relevant to floodplain commons in other countries. How can ecosystems and associated benefits that have traditionally accrued to the poor be maintained when these are based on seasonal commons and the private landowners can benefit from new opportunities that change land use, the physical environment and commons access?

\section{ACKNOWLEDGEMENTS}

This study was supported by a British Academy small grant awarded to Dr Parvin Sultana of Middlesex University. We are grateful to the many operators of floodplain aquaculture and local people who helped with the investigation, and to Habib Ahmed and Akram Hossain for assistance in conducting the inventory.

\section{REFERENCES}

Allen, R. C. 1992. Enclosure and the Yeomen. Oxford: Clarendon Press.

Brammer, H. 2000. Flood hazard vulnerability and flood disasters in Bangladesh. In Floods (vol. 1), ed. D. J. Parker, 100-115. London: Routledge.

Chambers, J. D. and G. E. Mingay. 1966. The Agricultural Revolution 1750-1800. London: Batsford.

Crafts, N. F. R. 1985. British economic growth during the industrial revolution. Oxford: Oxford University Press.

Department of Fisheries. 2006. National Fisheries Strategy and Action Plan. Dhaka: Department of Fisheries.

Hammond, J. L. and B. Hammond. [1911] 1987. The Village Labourer 1760-1832. reprinted 1987, Gloucester: Allan Sutton.

Hillel, D. 1992. Out of the Earth: Civilisation and the life of the soil. London: Aurum.

Middendorp, A. J., P. M. Thompson and R. S. Pomeroy, eds. 1999. Sustainable Inland Fisheries Management in Bangladesh. ICLARM Conference Proceedings 58. Manila: International Center for Living Aquatic Resources Management.

Ministry of Water Resources. 2001. Guidelines for participatory water management. Dhaka: Ministry of Water Resources, Government of the People's Republic of Bangladesh.

Mustafa, M. G. and A. C. Brooks. 2009. A comparative study of two seasonal floodplain aquaculture systems in Bangladesh. Water Policy 11 Supplement 1:6979. 
Narain, U., S. Gupta and K. van't Veld. 2005. Poverty and the Environment: Exploring the Relationship between Household Incomes, Private Assets, and Natural Assets. Washington DC: Resources for the Future.

Neeson, J. M. 1993. Commoners, Common right, enclosure and social change in England 1700-1820. Cambridge: Cambridge University Press.

Overton, M. 1996. Agricultural Revolution in England: The Transformation of the Agrarian Economy 1500-1850. Cambridge: Cambridge University Press Ramsar. 2001. Wetland Values and Functions. Gland: Ramsar Convention Secretariat.

Rahman, A.A., A.H.G. Quddus, B. Pokrant and M.L. Ali. (eds.). 2006. Shrimp Farming and Industry: Sustainability, Trade and Livelihoods. Dhaka: Bangladesh Centre for Advanced Studies and The University Press Ltd.

Soussan, J. and A. Datta. 1998. Community partnership for sustainable water management: experiences of the BWDB Systems Rehabilitation Project Vol 1, summary report. Dhaka: University Press Ltd.

Thompson, P. and L. Colavito. 2007. Economic value of Bangladesh wetlands. MACH Technical Paper 6. Dhaka: Winrock International.

Thompson, P., N. Roos, P. Sultana and S. H. Thilsted. 2002. Changing Significance of Inland Fisheries for Livelihoods and Nutrition in Bangladesh. Journal of Crop Production 6(1-2):249-317.

Thompson, P. M., P. Sultana and A. K. M. Firoz Khan. 2005. Aquaculture Extension Impacts in Bangladesh: a case study from Kapasia, Gazipur. Technical Report 63, Penang, Malaysia: WorldFish Center.

Thompson, P. M., P. Sultana and N. Islam. 2003. Lessons from community based management of floodplain fisheries in Bangladesh. Journal of Environmental Management 69(3):307-321.

Toufique, K. A. and R. Gregory. 2008. Common waters and private lands: Distributional impacts of floodplain aquaculture in Bangladesh. Food Policy 33(6):587-594.

Wagret, P. 1967. Polderlands. London: Methuen. 